\title{
Kapás Judit*
}

\section{Schumpeter hatalmas szellemi hagyatéka}

\author{
Beszámoló az International Schumpeter Society „Innovation, Competition and Growth: \\ Schumpeterian Perspectives" címü 11. évi konferenciájáról \\ (2006. június 21-24, Nizza - Sophia Antipolis)
}

\section{Bevezetés}

Az International Schumpeter Society ${ }^{1}$ felvállalt célja és annak megvalósítása tekintetében a legjelentősebb nemzetközi közgazdasági társaságok közé tartozik. A Társaság a Joseph Alois Schumpeter ${ }^{2}$ által elindított és képviselt dinamikus-evolúciós szemléletű közgazdasági hagyomány ápolására és továbbfejlesztésére törekszik. Elsősorban a fejlett országok gazdasági fejlődésének és szerkezeti átalakulásának kutatását állítja a középpontba, kiemelt figyelmet szentelve ebben a vállalkozónak, illetve az általa megvalósított innovációnak.

A névadó tudós, Schumpeter a kapitalista gazdaság fejlődését revolúciók sorozatának tekintette, amelyben a vállalkozás központi szerepet játszik: „Gazdasági fejlődésről akkor beszélhetünk, ha az új kombinációk hirtelen, lökésszerüen következnek be” (Schumpeter 1934 (1980): 111). Schumpeter felfogása szerint az innovátor-vállalkozó azáltal zavarja meg a körfolyamatot (circular flow), hogy új módokon cselekszik, vagy új dolgokat csinál. Ezzel a vállalkozó a hosszú távú gazdasági fejlődésben játszik szerepet, a kapitalizmus evolúciójának forrása, az „alkotó rombolás” megvalósítója. Leggyakrabban így vagy ehhez hasonlóan szokták a schumpeteri hagyatékot összefoglalni. Ezzel szemben engem a Társaság idei konferenciája ${ }^{3}$ arról győzött meg, hogy Schumpeter elmélete sokkal sokszínübb, hagyatéka sokkal gazdagabb, mint a fenti szokásos summázás.

A hagyaték sokszínűsége már a szekciók összetételében is tükröződött. Ezeket felsorolni lehetetlen egy rövid beszámoló keretében, csak ízelítőként villantok fel néhány témát: szervezeti rutinok és tanulás; vállalati dinamika és vállalkozás; szervezeti változás és innováció; $\mathrm{K}+\mathrm{F}$ stratégiák; verseny, tudomány és termelékenység; verseny és technológia; regionális növekedés; üzleti ciklusok; iparági tanulmányok; növekedési modellek.

\footnotetext{
Kapás Judit a Debreceni Egyetem Közgazdaságtan tanszékének docense. E-mail: judit.kapas@econ.unideb.hu. A szerzö konferencián tartott "The Evolution of Firm Organization: From the Factory through the M-form to the Project-based Firm" címü elöadása az OTKA T049602 számú kutatás keretében készült.

${ }^{1}$ A társaság honlapja: http://www.iss-evec.de/

2 Schumpeter életének és munkásságának kiváló összefoglalóját adja Haberler (1950).

${ }^{3}$ A konferencia honlapja: http://www.schumpeter2006.org
} 
A konferencia négy napja alatt hozzávetőleg 320 előadás hangzott el a szekciókban, a plenáris előadásokon nyolc kiváló tudóst hallhattunk, és persze a kávé- vagy ebédszünetekben kifejtett vélemények is sok esetben felértek egy-egy előadással. A konferencia, annak egész légköre páratlanul izgalmas szellemi élmény nyújtott, azt hiszem, minden résztvevőnek. Majdnem lehetetlen beszámolót írni egy ilyen eseményről, ezért e helyen csupán egy válogatást tudok adni, ám ez köszönő viszonyban sincs a teljességgel.

\section{Plenáris előadások}

A legnagyobb figyelem egyértelmüen Philippe Aghion ${ }^{4}$ (Harvard University) és William Baumol (Princeton University) előadásait kísérte, s talán mindketten aranyérmet érdemelnének, ha ez verseny lett volna. Philippe Aghion a kortárs növekedéselmélet egyik legjelentősebb „alkotója”, az ún. schumpeteri növekedéselmélet egyik kidolgozója. ${ }^{5}$ Elöadásának címe - nem meglepö módon - The Case for Schumpeterian Growth Theory volt. Schumpeter hagyatéka tehát nála nyilvánvaló. William Baumol idős kora ellenére fantasztikus szellemi frissességröl tett tanúbizonyságot Toward Restoration into Microtheory: Inventors and Entrepreneurs címü előadása és valamennyi hozzászólása során.

Philippe Aghion formalizált elméletének ${ }^{6}$ részletes bemutatása helyett franciás temperamentummal tartott, magával sodró előadásában inkább elmélete jelentőségéről beszélt: azt mutatta meg, hogy a schumpeteri növekedéselmélet miért képes jobb gazdaságpolitikai ajánlásokat adni, mint a konkurens növekedéselméletek. Hiszen szerinte a növekedéselméletnek valójában arra kellene választ adnia, hogy hogyan lehet a növekedést ösztönözni. Elsőként azt magyarázta, hogy sem a Solow-modellből, sem az endogén növekedéselméletből nem következnek gazdaságpolitikai tanácsok. Ezzel szemben saját elméletéből igen. Ebben a modellben az innováció $(\mathrm{K}+\mathrm{F})$ vezérli a növekedést. Aghion szerint elmélete rugalmasan képes kezelni azt is, hogy a növekedés hogyan függ az innováció utáni helyzettől: a növekedés úgy érhető el, hogy imitáljuk a világ termelési lehetőségének határán lévő vállalatokat. Ennek megfelelően a politika attól függ, hogy milyen messze vagyunk a határtól. Aghion ezek után a rivális elméletek között az AK-modellel és Romer elméletével (product variety paradigm) foglalkozott. Pontosabban szólva saját és e két elmélet összevetését adta néhány, felfogása szerint fontos szempont mentén, úgymint a belépés, kilépés és monopólium. Míg például az AK-modell, mivel tökéletes versenyt tételez fel, semmit sem tud mondani arról, hogy serkenti-e a növekedést a belépés, és Romer modellje mindig növekedést serkentőnek gondolja azt, addig a schumpeteri modell attól függően, hogy a világ termelési lehetőségének határához közel vagy távol vagyunk, kétféle hatást képes azonosítani: a határhoz közel a belépés növeli a teljes tényező termelékenységet,

\footnotetext{
${ }^{4}$ Honlapja: http://post.economics.harvard.edu/faculty/aghion/aghion.html

${ }_{5}$ Philippe Aghion társszerzöként írt könyve (Aghion, Ph. - Griffith, R. (2005) Competition and Economic Growth. Reconciling Theory and Evidence (Zeuthen Lectures), Cambridge, Massachusetts: The MIT Press) a konferencián megosztva a Társaság által odaítélt Schumpeter-dijat kapta. A dijat minden esetben olyan szerzőknek ítélik oda, akik két konferencia közötti időszakban a schumpeteri hagyományokat jelentős monográfiában vitték tovább. Az idei dijazott művek még: Richard N. Langlois (2006) The Dynamics of Industrial Capitalism. Schumpeter, Chandler, and the New Economy. London: Routledge, és Richard Lipsey, Kenneth I. Carlaw és Clifford T. Bekar (2006) Economic Transformations: General Purpose Technologies and Long-term Economic Growth. Oxford: Oxford University Press.

${ }^{6}$ Az elmélet rövid, de világos összefoglalásáról lásd: Aghion (2004).
} 
míg távol nem. Összességében elmélete erényének Aghion azt tartja, hogy abból a gazdaságpolitika számára különféle ajánlásokat lehet megfogalmazni.

William Baumol a neoklasszikus közgazdászok között egyedülállónak számít abban, hogy a mainstreamelméletből hiányzó vállalkozót „komolyan” veszi. Baumol munkásságának egy jelentékeny része a vállalkozás és a neoklasszikus közgazdaságtan valamiféle közelítéséről szól, bár az innovátor-vállalkozó matematikai modellezését nem tartja lehetségesnek, mert a vállalkozó akciói nem ismétlődőek, és nincs bennük szisztematikus kalkuláció (Baumol 1993). A vállalkozás produktív, improduktív és destruktív fajtáinak elkülönítésével (Baumol 1990) jelentős mértékben hozzájárult a növekedés és a vállalkozás közötti kapcsolat jobb megértéséhez, ezzel mintegy ki is szélesítette a vállalkozás koncepcióját, illetve „beszélő viszonyba” hozta az osztrák vállalkozáselmélettel (Kirzner 1973). Baumol előadása legújabb könyvéhez (Baumol 2002) kapcsolódott. Elsőként az általa Dávid-Góliátnak nevezett jelenségről beszélt. A „Dávidok” a radikális innovációt végrehajtó kis cégek, akik sokszor legyőzik a „Góliátokat”. Érdekes megvizsgálni ennek hátterét: bár a nagy cégek költik el a K+F kiadások túlnyomó részét (2000-ben az USA-ban a $\mathrm{K}+\mathrm{F}$ kiadások $46 \%$-át 146 cég viselte), mégis többnyire csak rutininnovációkat végeznek, s ez okozza „vereségüket”. Ezt követöen Baumol bámulatosan egyszerü eszközökkel, gyakorlatilag csak keresleti és kínálati görbéket használva megmutatta, hogy milyen úton kell elindulni ahhoz, hogy a mikroökonómiába „becsempésszük” a vállalkozót.

A plenáris elöadások sorában Ulrich Witt ${ }^{7}$ (Max-Planck Intézet) The Growth of Consumption - An Evolutionary Approach címü előadásában nagyon izgalmas kérdést elemzett: mit tesz a fogyasztó, ha jövedelme nő. A magyarázat evolúciós jellege olyan szempontokat volt képes bekapcsolni a megértésbe, amelyek hiányoznak a neoklasszikus mikroökonómiából: a preferenciák nem adottak, hanem egy időigényes folyamat során fejlődnek ki; a termékek köre az időben hihetetlen módon kiszélesedik. Ulrich Witt szerint ugyanis a hagyományos hasznosságfüggvény alapján nehéz megmagyarázni a fogyasztás hosszú távú fejlődését, miszerint a jövedelem jelentős emelkedése ellenére a fogyasztás nem telítődik. Ezért szerinte a hasznosság helyett az igényeket (wants) kell vizsgálni, azaz a döntő kérdés az, hogy az emberek mindennapi tevékenységükkel milyen igényeket kívánnak kielégíteni, és hogy ezek az igények hogyan változnak az időben. A kognitív pszichológia alapján bizonyos magatartási minták azonosíthatók ugyan, de Witt végső soron amellett érvelt, hogy a termékkör szélesedése és a fogyasztók fogyasztási specializálódása magyarázza a fogyasztás hosszú távú alakulását.

\section{Témák a szekciókból}

A szekciókban elhangzott előadások - evolúciós nyelven szólva - gazdag változatosságot mutattak. Voltak prezentációk, amelyek Schumpeter újrafelfedezését jelentették, azaz olyan schumpeteri gondolatokat „poroltak le” és értelmeztek a mai modern közgazdaságtan keretében, amelyek többnyire a feledés homályába merültek. Ennek sorában Richard Aréna (Université de Sophia Antipolis) és Pierre Garrouste (Université de Lyon II) egymástól függetlenül Schumpeter racionalitásra vonatkozó nézeteit elemezte és értelmezte a korlátozott racionalitás kontextusában. Pierre Garrouste Schumpeter nézeteit Morgenstern

\footnotetext{
${ }^{7}$ Honlapja: http://www.mpiew-jena.mpg.de/english/staff/index.html
} 
nézeteivel vetette össze (The Actuality of Schumpeter's Concept of Rationality), míg Richard Aréna a kétféle schumpeteri racionalitás koncepciót a rutin és a vállalkozói magatartással kapcsolta össze Economic Rationality and the Emergence of Institutions: A Schumpeterian View címü előadásában. Agnès Festré (Université de Sophia Antipolis) Schumpeter pénzre és a bankokra vonatkozó elméletét elemezte intézményi keretben, azaz arra helyezte a hangsúlyt, hogy a pénz és a bankok mennyiben testesítenek meg magatartási mintákat Schumpeternél (Schumpeter's Analysis of Banking and Finance: An Evolutionary or Rather an Institutional Approach?).

Mások, köztük Richard Langlois (Connecticut University) vagy Brian Loasby (University of Stirling), előadásai a neoklasszikus közgazdaságtan kritikáját is adták. Langlois Ghost in the Sausage Machine címü elöadásában arról beszélt, hogy mit jelent és miért félrevezető a vállalat termelési függvény (azaz kolbászgyár) koncepciója. Brian Loasby Motivation, Innovation and Co-oordination címmel tartott előadásában a kognitív tényezők koordinációban játszott szerepét elemezte.

Jackie Kraft (CNRS) és Michael Dietrich (University of Sheffield) The Firm in Economics and History: Towards an Historically Relevant Economics of the Firm címü elöadásukban azt hangsúlyozták, hogy a vállalatelméletnek a különböző történelmi kontextusok megmagyarázása érdekében plurálisnak kell lennie. Szerintük nem lehetséges egyetlen elmélet keretében megérteni a sokféle történelmi helyzetben létező vállalatot. Felfogásukban a plurális vállalatelméletet bizonyos mértékig az empíriának kell vezetnie. Előadásukban ennek a plurális vállalatelméletnek az alapjait vázolták fel. Egyrészt a vállalat egy technológia egység, másrészt egy intézmény. Ez a kettősség határozza meg a vállalat természetét. Kraft és Dietrich az alábbi egyszerủ sémán (1. ábra) mutatták be, hogy az egyes vállalatelméletek a vállalat mely aspektusainak a magyarázatában erösek.

\section{A vállalat modellje}

1. ábra:

\begin{tabular}{|c|c|c|c|}
\hline $\begin{array}{c}\text { hosszú távú } \\
\text { szemlélet }\end{array}$ & $K$ & $\begin{array}{l}(5) \\
(6) \\
\end{array}$ & $\begin{array}{l}\text { hatékonysági } \\
\text { szempontok }\end{array}$ \\
\hline 4 & & & $\Delta$ \\
\hline (2) & $\longrightarrow$ & $\begin{array}{l}\text { technológiai } \\
\text { ténvezők }\end{array}$ & (3) \\
\hline
\end{tabular}

Az (1) nyíl az új intézményi közgazdaságtant jelenti, a (2) az osztrák vállalatelméletet. Ezektől azonban sokkal izgalmasabb aspektusokat képviselnek a (3) és (4) reláció, azaz az előbbi kettő ellentétes viszonyai. A (3) hatás szerint a hatékonysági menedzsment hatással van a vállalat technológiájára. Erre a hatásra még kevés figyelmet szentelt a vállalatelmélet. A (4) nyíl azt fejezi ki, hogy amikor a vállalat például beruházási döntéseket hoz, ezek a sunk költségek technológiai útfüggőséghez vezethetnek. Az (5) reláció a (4) reláció szervezeti megfelelője: a hatékony szerződési és motivációs rendszer felállításának sunk költségei blokkolhatják a hosszú távú szervezeti változásokat. A (6) viszony a kompetencia alapú vállalatelméletet jelenti. E modell bemutatása után a két szerző a jól ismert General 
Motors - Fisher Body-eset négy újabb interpretációját ${ }^{8}$ elemezte az általuk bemutatott keretben. Modelljükben érthetővé vált, hogy miért értelmezik ugyanazt az esetet a különböző szerzők eltérő módokon: mindannyian más-más relációra összpontosítanak. Kraft és Dietrich tehát az útfüggőség és a pluralitás schumpeteri hagyományát vitték tovább.

$\mathrm{Az}$ útfüggőség problémája Paul Windrum (Manchester University), Andreas Reinstaller (Vienna University) és Werner Hölz (WIFO) Short-term Gain Long-term Pain?: The Long-run Implications of Outsourcing for Organisational Innovation and Productivity címü előadásában is szerepet kapott. A szerzők a szervezeti innovációk, az ICT és a vertikális dezintegráció közötti kapcsolatot vizsgálták. Szervezeti innovációs modelljükben a vezető célja, hogy olyan szervezeti struktúrát hozzon létre, amelyben a vállalat tevékenységeit a leghatékonyabban lehet koordinálni. Az innováció során a vezetö arról dönt, hogy házon belül tartja a tevékenységet, illetőleg kiszervezi azt. Ezt a döntést az befolyásolja, hogy mekkorák a házon belüli megszervezés információs költségei a szállítóval való kapcsolattartás információs költségeihez képest. A modell felépítése után a szerzők szimulációt végeztek a rövid és hosszú távú hatások vizsgálatára. Eredményeik szerint a vezető „beragadhat" az alacsony termelékenységnövekedéssel járó pályára, ahol pusztán az alacsonyabb költségek okán kiszervezi a tevékenységeket, hosszú távon termelékenységi veszteségeket szenvedve el. Ennek az az oka, hogy kiszervezik egy lehetséges szervezeti innováció moduláris elemét, amely szinergikusan kapcsolódna a többi elemhez.

Nem hiányoztak természetesen az ICT-szektorhoz kapcsolódó témák sem. Ezek sorában Ludovic Dibiaggio (Université de Sophia-Antipolis) a félvezetőgyártó iparág evolúciójával foglalkozott a Technological Specialisation and Evolution of the Semiconductor Industry című előadásában. Az előadás a technológiai tudás evolúcióját vizsgálta az említett iparágban. A szerző megmutatta, hogy a vállalatok azáltal, hogy többnyire kiterjesztették technológiai portfoliójukat, és leszűkítették tudásbázisukat, olyan technológiai kombinációkat választottak, amelyekben a komplementaritás magas volt. Ugyanakkor az azonos piacon versenyző vállalatok nem feltétlenül specializálódtak technológiai alapon.

Masaaki Hirooka (Institute of Technoeconomics, Koyama) Fractal Structure of Innovation Paradigm and Evolutionary Rebound Through Institutional Change címmel tartott előadásában a hosszú távú (Kondratyev) ciklusok segítségével elemezte az innovációs rendszereket. Úgy találta, hogy két Kondratyev-ciklus között létezik egy hosszabb ciklus is, amely egy innovációs hullámot testesít meg. Egy innovációs paradigma három útszakaszból áll: technológia, fejlődés és diffúzió. E pályák mentén matematikai egyenletekkel vizsgálta a fraktálokat. Háromféle fraktált talált az innovációk során: lánc-, összekapcsolt- és rendszerfraktálokat. A termékinnovációk láncfraktálokat képeznek a fejlödési pálya mentén. A létező iparágakban a technológiai innovációk összekapcsolódó fraktálokat hoznak létre, míg gyakran rendszerfraktálok is létre jönnek. Következtetése szerint tehát az innovációs rendszerek fraktálokból állnak. Ez alapján elmondható, hogy az innovációk komplex rendszerek, illetve a fraktálképződés - maga is pályákat hozva létre - a technológiai paradigmák elterjedésének vezérlője.

A kockázati tőke igazi schumpeteri téma, sok előadás kapcsolódott ehhez is. Izgalmas kérdést elemzett formális tanulmányában David Mas és Annick Vines (mindketten Université de Paris II) Why Do We Need Venture Capital? The Role of Competent

\footnotetext{
${ }^{8}$ Ezek a Journal of Law and Economics-ban jelentek meg 2000-ben, a szerzők: Klein, Coase, Freeland, Casadesus-Masanell és Spulber.
} 
Intermediaries in the Creation Process címmel. Ök a vállalatelméletből és az evolúciós mikroökonómiából vett eszközökkel elemezték a kockázati tőke szerepét. Megmutatták, hogy a kockázati tőkés kompetenciája önmagában nem elég: a hatékony piaci screeningnek az is feltétele, hogy kellő számú kezdő vállalkozás legyen a piacon. Formális modelljükben azt is megmagyarázták, hogy a kockázati tőkés szelekciós mechanizmusa hogyan viszi a piacot az egyensúly felé. Ezt szimulációjuk is alátámasztotta.

Talán a fenti rövid beszámolómnak sikerült érzékeltetnie, mennyire sokszínủek voltak az előadások mind témájukat, mind az alkalmazott eszközöket, mind pedig azt tekintve, hogy mennyiben szakadtak el a neoklasszikus közgazdaságtantól.

\section{Zárszó}

Ezt a gazdag szellemi hagyatékot szemlélve, amelyröl a konferencia is képet adott, felmerül a kérdés, hogy miért nincs schumpeteri iskola a közgazdaságtanban. Haberler (1950) közvetlenül Schumpeter halála után úgy látta, hogy egyrészt azért, mert Schumpeter soha nem volt sem a kapitalizmus, sem a szocializmus, sem a tervezés, sem semmilyen „izmus” elkötelezett híve. Schumpeter egy tudós intellektuel volt. Másrészt Schumpeter nyitott gondolkodása okán minden elméletben talált hasznos és elfogadható nézeteket, ezért nem szállt síkra egyik elmélet érdekében sem. Így nincs tehát schumpeteri iskola, viszont Schumpeter szellemi hagyatéka hatalmas.

\section{Hivatkozások}

Aghion, Ph. (2004): Growth and Development: A Schumpeterian Approach. Annals of Economics and Finance 5:1-25.

Baumol, W. J. (1990): Entrepreneurship: Productive, Unproductive and Destructive. Journal of Political Economy 98:893-919.

Baumol, W. J. (1993): Formal Entrepreneurship Theory in Economics: Existence and Bounds. Journal of Business Venturing 8:197-210.

Baumol, W. J. (2002): The Free-Market Innovation Machine - Analyzing the Growth Miracle of Capitalism. New Jersey: Princeton University Press.

Haberler, G. (1950): Joseph Alois Schumpeter 1883-1950. Quarterly Journal of Economics 64. 3:333-372.

Kirzner, I. M. (1973): Competition and Entrepreneurship. Chicago: University of Chicago Press.

Schumpeter, J. A. (1934): A gazdasági fejlődés elmélete. Közgazdasági és Jogi Könyvkiadó. Budapest, 1980. 